(148)

的蛛䭾言福北王夫

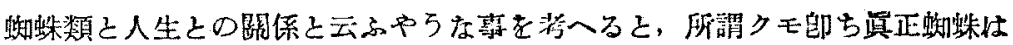
本邦では㱠んど䦓係がないやらであるが，昆路等を捕食する事から云つて陰で 妙なからす働いてるるものであらう。ある一種のクモがー日にどれ位を゙んな

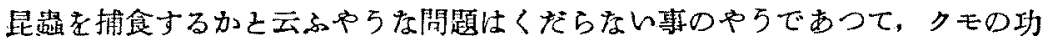

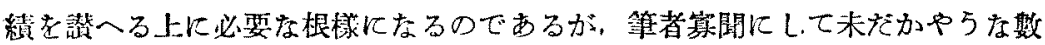
量的の研究がないやらでする。被害と云ふ方面から見れば败蛛類の中ではダニ 類が最も重要なものであると思はれるが，之就いても數量的な報告㹥むり ないや5に思ふ。人生との關係から云へ代ダ二類は最も閶心を持をるべきるの

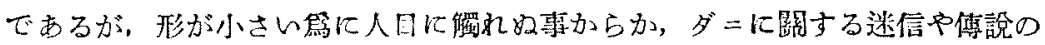

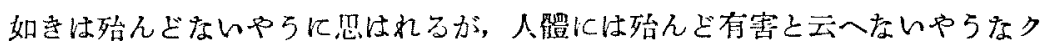
モの扎は色々あるうである。

クモに關聯して一般の人の想記する所壮あ生りよい印像はないやうであつて

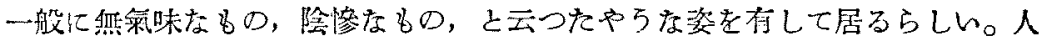

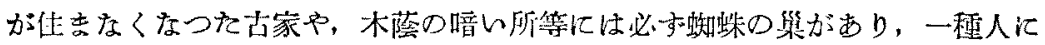
濑がられるものである。此クモ類の热筷味な肢や網に關聯してクモならぬ他の

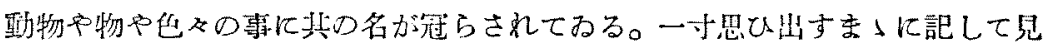
ても，㩋物にクモヒトデ・クモザル・クモガヒ・クモガニ・カハグモ・ウミグ モ・Arachnactis 等があり，植物にクモランガあるが，之等はクモの肢の長 く，形の似て居る柔から來てるるのであらら。及クモノスカビやクモノスシダ 等の椎物名はクモの集から來たるのであらう。手足の指趾が細長くなる晇形に arachnodactylia 己名付けられて居る事注クモの肢からであららし，㨫の軟膜

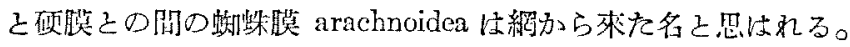

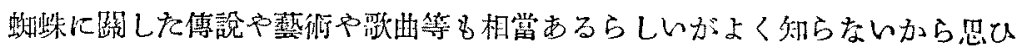

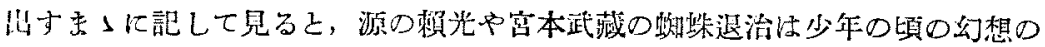




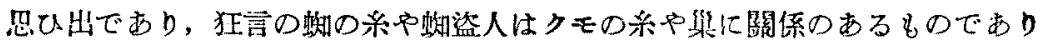

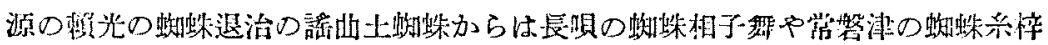

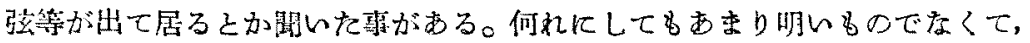
人を害するものとか，夜陰の忍び込に絧に引加っつて勘けなくなつたとか云ふ 嘌い方面の事であるが，クモが喑い所にばかり居るものでなく，日向の朋い所

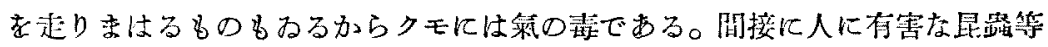

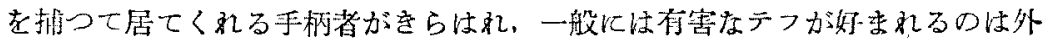

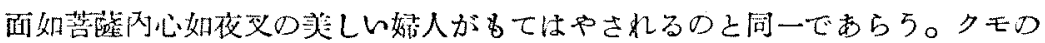

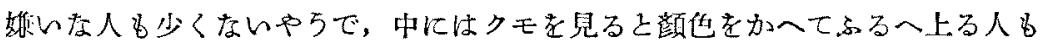

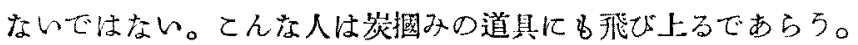

无タ一面かやうにをらはれるばかりではなくササガニの名の下に歌によまれ

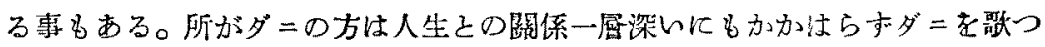

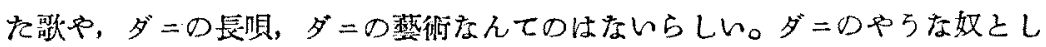
つこくしがみついて吸血する寞にいやならるさい奴の事位に用てられる。けれ ぞも淡水產の自由生活のダ=等には女の子の着物の柄にしてもよいやらなしゃ れた模樣をとつて居るものもある。

本邦虐のクモには㗪みついて大して害を與人るものはないやらたが，中には 相當有害なるのも居るらしく，クモに喽まれたる徽候に arachnitis（=arach-

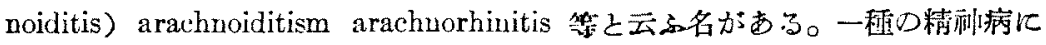
Tarantism と云ふのがあつて, Tarantula と云ふクモに哓まれるととステリー 贆になり，踊りまはるとなほると云ふ迷信みたいなものがあるが，てれは或人

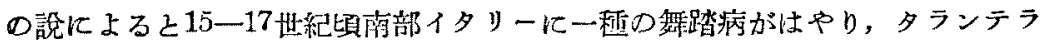

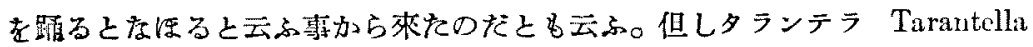
と云ふ舞踏曲は Taranto と云ふ地名加ら來たのたと云はれる。此方が本當代 らら。ダニによつて起る病氣は acariasis である。サッリは蛇蠋の如くで，お そろしくをらはれて居るが，蝎と云ふ字洁もとはキクヒムシの事で，サッリは 


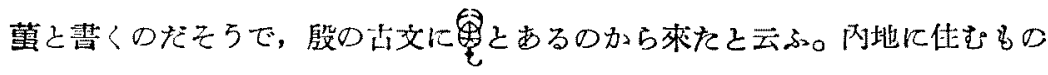

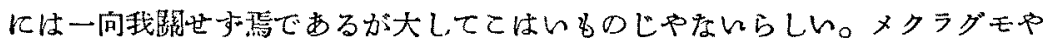
サンリモドキやアトシサリ梦は闍題にならないものらしい。クモの絲の利用法

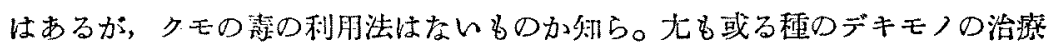

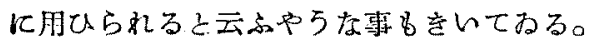

\section{會 屓佳所變更}

宗都书左京區吉四中大路町 $34>50$

整北市兒玉町 $3 ， 6$

東京市江月川四本小松川3 3666

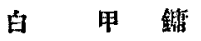

蓝島是

百會秋次

\section{新入面員}

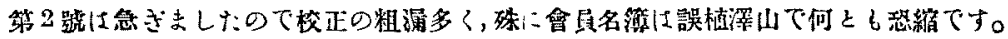

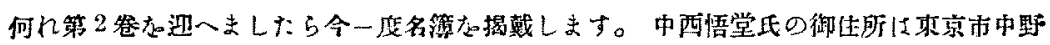

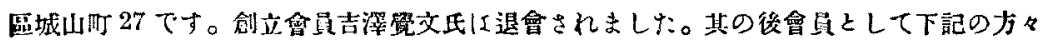
か迎へましけが創古會貝の受付仕しう致しません。

\section{邻严合熷}

本京市中野區上高田 $1>83$

宗都方河原町二佟南入西侧岛津製作所標本部

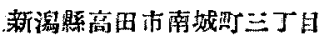

P. O. Box 20.5, Zamboanga, Philippine Is.
小川典 弘

在 苳 謹一

居，野涕一郎

桑島䄰三

\section{通棠萻面}

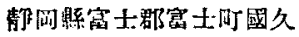

盟 㵏症

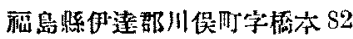

高 栝 直 敏

京都市深草第一小學校

太田正 亞

盛成方仙北断 63

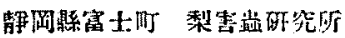

瀨川幸一

朝解京城師籍學校

矢 徣 正 俊

朝䬺釜山公立巾鼠校

传落月二

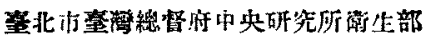

武木直素

在賀市興望町 1368

森下缽

山口百人 